\title{
Ownership Structure and Dividend per Share of Listed Manufacturing Companies in Sri Lanka
}

\author{
S. Jeyan Suganya and Lingesiya Kengatharan \\ Department of Financial Management, University of Jaffna, Sri Lanka. \\ Corresponding email address: lingesiya@univ.jfn.ac.lk
}

Received: 17 July 2017

Accepted: 17 August 2017

\begin{abstract}
The aim of this study was to investigate the relationship between ownership structure and dividend per share of manufacturing companies listed on the Colombo Stock Exchange in Sri Lanka. Institutional ownership, managerial ownership and foreign ownership were considered as explanatory variables while dividend per share was used as response variable. Control variables were firm size and firm leverage. Secondary data were collected from the annual report of 26 randomly selected manufacturing companies for 5 years from 2011 to 2015. Descriptive and inferential statistics were used to analyze the data using SPSS. Results of this study revealed that institutional ownership had significant negative relationship with dividend per share. On the other hand, firm size significantly positively related with dividend per share. Thus it can be used as an alternative tool that can support to minimize the agency problem.
\end{abstract}

Key words: Institutional ownership, Managerial ownership, Foreign ownership, Dividend per share

\section{Introduction}

The ultimate objective of companies is to maximize the shareholders wealth and main task of the managers is maximization of owner's wealth (Pamela, Frank and Fabozzi, 2010). Whenever the financial manager makes whatever decisions such as financing decision, investment decision and dividend decision, they should be 
able to maximize value of the firm (Pamela, Frank and Fabozzi, 2010). Each entity type has a unique ownership structure. Managerial owners, individual owners, institutional owners, foreign owners and family owners can be components in the ownership structure of a company. These components are representing the ownership structure in most of the Sri Lankan companies. Previous studies suggested that share ownership in Sri Lanka is focused in a considerable percentage (Mapitiya, Ajward and Samanthi, 2015), because ownership structure is an influential factor on firm policies including dividend policy. Usually various factors affect value of the firm. One of the most important factors is dividend policy. Dividend policy means the formation of a policy by the company regarding payment of dividend from profits to ordinary shareholder years to year (Bhat, 2008). The decisiveness of theories on perceived importance of dividend policy in determining the corporations' value has made it one of the most debatable topics for researchers. The question mostly arises that why firms pay dividends. This question has been the subject of debate for many years.

Three main theories related to dividend policy have been developed in order to find out the impact of dividend policy on value of the firm. Modigliani-Miller's model is considered as dividend irrelevance theory while Walter's model and Gordon's model are considered as dividend relevance theories as they argue that the dividend policy of a firm affects the value of the firm. In the pre-Miller and Modigliani era, it was believed that increasing dividends would always increase market value. Miller and Modigliani (1961) established that in a perfect capital market, given an investment policy, dividend is irrelevant in determining share value. Empirically, however, it is observed that a change in dividend policy has a significant impact on the share price (e.g: Tahir, Aslam and Akhtar, 2014; Ehsan et al., 2013; Afza and Mirza , 2010).

Dividend policy is an influential control vehicle to reduce the conflicting interests of the shareholders and managers because shareholders are interested in getting dividends, but managers prefer to retain earnings. Managers want to retain earnings for maintaining higher control over the resources. It is considered as agency problem. Therefore, corporate governance pays huge attention in this study as it arose out of agency theory.

Peradeniya Management Review - Vol. I , No.01 , (June)2018 
The relationship between agency cost and dividend policy has been a current development in the corporate finance theory that focused on how dividend payout can be used to control the agency cost of the firm (Syed et al., 2010). According to them, if dividends are not paid to the shareholders, the managers will start using these resources for their private benefits. Dividend policy helps the firms to know that how they can control the agency costs by handling the dividend policy.

Therefore, an important attention has been given by the researchers on dividends to shareholders. The purpose of this study is to investigate the relationship between ownership structure and dividend per share of listed manufacturing companies on Colombo Stock Exchange (CSE) in Sri Lanka. Because contribution of manufacturing sector to the GDP growth in Sri Lanka was increased due to the expansion in manufacturing in past few years (Annual report of CBSL 2016). Therefore, it should have knowledge regarding the division of ownership structure to enhance its contribution to the GDP further in the future years. Many researchers focused to conduct the researches in developed countries to find out the relationship between the ownership structures and dividend policy. However, only few studies focused on the relationship between ownership structure and dividend policy in developing counties. Therefore, present study intends to find out the relationship between ownership structure and dividend per share of listed manufacturing companies in Sri Lanka. Sri Lanka is an emerging country which tends to have different cultural values, norms, traits, religion, beliefs and life style. Hence, this study aims to fill that gap by studying the relationship between ownership structure and dividend per share by considering the different classes of ownership structures such as institutional, managerial and foreign ownership structures in the Sri Lankan manufacturing companies. 


\section{Literature review}

\subsection{Theoretical framework}

The main theories related to ownership structure and dividend policies, namely agency theory and signaling theory, are discussed below.

\subsubsection{Agency theory}

Jensen and Meckling (1976) developed the agency theory. It says that different incentives between agents (managers) and principals (shareholders) can cause problems. Short term profits can be mostly preferred by managers of a company to increase their own wealth, but sustainable long term growth can be preferred by owners of the firm. Therefore, conflict can be arisen between these two parties. Intuitively, dividends can play a role in this process as well. Managers could satisfy the needs of the owners of the firm by paying out dividends.

\subsubsection{Signaling theory}

Signaling theory suggests that information asymmetry between managers and outside investors is one of the key market imperfections that make hedging potentially beneficial (Dionne and Ouederni, 2011). There is an argument in this theory that stock price changes with dividend announcements occur because investors consider these announcements as signals of management's earnings forecasts. Thus, the actual dividend is concerned lesser by investors than the information content of the dividend announcements (Besley and Brigham, 2008).

\subsection{Empirical review}

\subsubsection{Institutional ownership and dividend policy}

Dividend serves a mechanism used to compensate shareholders for contributing to the asset of a company. Institutional shareholders like banks, insurance companies, trustee funds and investment companies hold people's money in 
trust to utilize it into profitable ventures. Therefore, they are expected to facilitate dividend payment in order to meet investors' expectation. But divergent of opinion and empirical findings make this assertion inconclusive. A study by Nuraddeen and Hasnah (2015) on impact of ownership structure on dividend policy of eight listed conglomerates firms in Nigeria for the period 20012010 showed a positive relationship between institutional ownership and dividend policy. Adeiza et al. (2015) also found a significant positive impact of institutional shareholding on dividend payout ratio in chemical paints companies listed in Nigeria.

\subsubsection{Managerial Ownership and Dividend Policy}

Kabiru, Adeiza, and Muhibudeen (2015) studied impact of corporate shareholding on dividend payout ratio of chemical and paints companies listed in Nigeria for the period from 2008 to 2013, found a significant negative impact of managerial shareholding on dividend payout ratio. Mirzae (2012) conducted a survey to find out the relationship between ownership structure and dividend policy of Tehran stock exchange and found insignificant relationship between managerial ownership and dividend policy. Ullah, Fida, and Khan (2012) investigated the determinants of the corporate dividend policy in the context of agency relationship by selecting 70 companies during the period 2003-2010. The study found a negative relationship between managerial ownership and dividend policy using both partial and full adjustment models. Sehrish and Afzal (2010) applied OLS, Logit and Probit regression and found that insiders' ownership (management ownership) and profitability show significant negative impact on dividend payment. While the result of logit and probit model show that individual ownership and insider ownership are negatively related with dividend policy, but profitability is positively significant relates to with dividend structure. Short, Zhang, and Keasey (2002) did not find evidence in support of the hypothesis that a negative association exists between dividend payout policy and managerial ownership for the U.K. companies. Strouraitis and Wu (2004) found that the impact of managerial ownership on dividend yield is positive particularly of the low growth firm in Japan. Tahir, Aslam and Akhtar (2014) 
conducted a survey to examine the impact of board composition and ownership structure on dividend policy using 18 companies from cement industry listed at Karachi Stock Exchange in Pakistan from 2008 to 2012. The result of the study revealed that there was a positive significant relationship between individual ownership and insider ownership with the dividend policy. Kumar (2003) found that corporate and directors ownership are positive and related in level with dividend policy. Nuraddeen and Hasnah (2015) conducted a study on the impact of ownership structure on dividend policy of listed conglomerates firms in Nigeria from using ten years data of eight companies from 2001 to 2010 and found a negative relationship between managerial ownership and dividend policy. Afza and Mirza (2010) examined the ownership structure and cash flows as determinants of corporate dividend policy in Pakistan using three years data for 100 companies. The results showed that managerial and individual ownership are negatively related whereas, operating cash-flow and profitability are positively related to cash dividend. Managerial ownership, individual ownership, operating cash flow and size are the most significant determinants of dividend behavior.

\subsubsection{Foreign ownership and dividend policy}

According to the agency theory, foreign investors may not have sufficient control over the operations of management due to the distance in geographical location. Therefore, the only way through which they can influence managers is to force them to pay dividend to reduce the level of free cash-flows available to them (Ullah et al., 2012). Adeiza et al. (2015) found a significant positive impact of foreign shareholding on dividend payout ratio in chemical paints companies listed in Nigeria. Lina, Suzan, Ola, and Imad (2012) investigated the effect of ownership structure on dividend pay-out policy of Jordanian industrial public companies for the period 2005-2007. The statistical result consistently supports a significant positive impact of foreign ownership on dividend pay-out policy. Ullah et al. (2012) investigated the determinants of corporate dividend policy in the context of agency relation using 70 firms from Karachi Stock Exchange KSE100 index for the period 2003 to 2010. Stepwise multiple regression has been 
used to analyze the influence of ownership structure on dividend payouts. The results showed a significant positive relationship between foreign share ownership and dividend pay-out. This will lead to less availability of the cash flows with the opportunities for the managers to expropriate the shareholders wealth, as suggested by the authors. Minimo and Makesh (2013) examined the impact of foreign institutional investors on corporate dividend policy in Indian firms whose ownership by foreign investors was five per cent or higher for the period from 2007-2011. The study found that foreign institutional investors with more than five per cent ownership do not have a significant impact on corporate dividends. Warrad et al. (2012) studied the effect of ownership structure on dividend payout policy in Jordanian context by examining all the industrial companies listed in the Airman stock exchange. The result of this research shows that there is no relationship between foreign ownership and dividend payout policy. Abdullah et al. (2012) studied the influence of ownership structure on dividend policy in Malaysian companies based on Lintner model. They found an insignificant relationship between foreign ownership and dividends.

According to the literature survey, this study hypothesized that $\mathbf{H}_{\mathbf{1}}$ : There is a significant relationship between ownership structure and dividend per share of listed manufacturing companies in Sri Lanka. Formulated hypothesis has been sub divided based on the components of ownership structure in the data analysis part.

\section{Research methodology}

\subsection{Sample and data collection}

The purpose of this study is to identify the relationship between ownership structure and dividend per share to provide empirical evidence regarding listed manufacturing sector in Sri Lanka. Population of manufacturing companies listed in the CSE, Sri Lanka was forty one (41). However, twenty six companies were taken randomly as the sample for this study. The data were derived from the financial reports of the sample firms available in the CSE for the period of five years from 2011 to 2015. 


\subsection{Mode of analysis}

This study uses sampled panel data restricted to companies listed. In order to analyze data collected from secondary sources, quantitative techniques were employed, namely descriptive statistics, correlation matrix and regression models.

\subsection{Research model}

Dividend policy is taken as response variable which is measured by dividend per share (DPS). Institutional ownership (INOS), managerial ownership (MOS) and foreign ownership (FOS) were used as independent variables. Firm size (FSZ) and firm leverage (FLV) were used as control variables.

The multiple linear regression model developed for the study as given below attempts to investigate the effect of ownership structure on dividend per share of selected manufacturing companies in Sri Lanka.

$D P S=\alpha+b_{1} I N O S+b_{2} M O S+b_{3} F O S+b_{4} F S Z+b_{5} F L V+$ (1)4. Data analysis and discussion

\subsection{Descriptive statistics}

Table 4.1: Descriptive Analysis

\begin{tabular}{cccccc}
\hline & $\mathrm{N}$ & Minimum & Maximum & Mean & Std. Deviation \\
\hline INOS & 130 & 0.263 & 0.931 & 0.743 & 0.158 \\
MOS & 130 & 0.021 & 0.736 & 0.072 & 0.163 \\
FOS & 130 & 0.016 & 0.853 & 0.193 & 0.256 \\
FSZ & 130 & 8.501 & 10.150 & 9.312 & 0.426 \\
FLV & 130 & 0.004 & 0.466 & 0.083 & 0.072 \\
DPS & 130 & 0.000 & 23.000 & 2.657 & 3.769 \\
\hline Valid N (list wise) & 130 & & & & \\
\hline
\end{tabular}

Source: Survey data 2017 
The dividend per share (dependent variable), ownership structure (independent variable) and control variables are initially examined with descriptive statistics as given in table 4.1. The standard deviation of dependent variable (DPS) is 3.769 which can be considered as highest deviation from mean of DPS. It indicates a substantial variation in the amount of dividend distribution in the listed manufacturing companies of Sri Lanka. This is due to the fact that some companies are not distributing any dividend while some companies are distributing their dividend as high as maximum value of 23 rupees per share. On average 2.657 rupees dividend is distributed by the sample companies. Mean of institutional ownership has highest value (0.743) than other ownership structures. It means most of the manufacturing companies in Sri Lanka have higher percentage of institutional ownership.

\subsection{Correlation analysis}

Table 4.2: Correlation Analysis

\begin{tabular}{|c|c|c|c|c|c|c|c|}
\hline & & (1) & (2) & (3) & (4) & (5) & $(1$ \\
\hline \multirow{3}{*}{$\begin{array}{l}\text { Institutional } \\
\text { ownership }\end{array}$} & Pearson Correlation & 1 & & & & & \\
\hline & Sig. (2-tailed) & & & & & & \\
\hline & $\mathrm{N}$ & 130 & & & & & \\
\hline \multirow{3}{*}{$\begin{array}{l}\text { Managerial } \\
\text { ownership }\end{array}$} & Pearson Correlation & $.781^{* *}$ & 1 & & & & \\
\hline & Sig. (2-tailed) & .000 & & & & & \\
\hline & $\mathrm{N}$ & 130 & 130 & & & & \\
\hline \multirow{3}{*}{$\begin{array}{l}\text { Foreign } \\
\text { ownership }\end{array}$} & Pearson Correlation & -.082 & $-.230^{* *}$ & 1 & & & \\
\hline & Sig. (2-tailed) & .353 & .009 & & & & \\
\hline & $\mathrm{N}$ & 130 & 130 & 130 & & & \\
\hline \multirow{3}{*}{ Firm size } & Pearson Correlation & $-.247^{*}$ & -.054 & .113 & 1 & & \\
\hline & Sig. (2-tailed) & .005 & .543 & .202 & & & \\
\hline & $\mathrm{N}$ & 130 & 130 & 130 & 130 & & \\
\hline \multirow{3}{*}{ Firm Leverage } & Pearson Correlation & -.053 & -.006 & -.117 & $.193^{\circ}$ & 1 & \\
\hline & Sig. (2-tailed) & .549 & 949 & 185 & .028 & & \\
\hline & $\mathrm{N}$ & 130 & 130 & 130 & 130 & 130 & \\
\hline \multirow{3}{*}{$\begin{array}{l}\text { Dividend per } \\
\text { share }\end{array}$} & Pearson Correlation & $-.317^{* *}$ & $-.203^{*}$ & -.023 & $.260^{* *}$ & .011 & \\
\hline & Sig. (2-tailed) & .000 & .020 & .791 & .003 & .899 & \\
\hline & $\mathrm{N}$ & 130 & 130 & 130 & 130 & 130 & \\
\hline
\end{tabular}


According to the table 4.2, correlation coefficient between the institutional ownership structure and dividend per share is -0.317 which is significant at 0.01 level. It means that there is weak negative significant relationship between institutional ownership structure and dividend per share. Correlation coefficient between the managerial ownership and dividend per share is -0.203 which is significant at 0.05 level, meaning that there is significant association between managerial ownership structure and dividend per share. There is an insignificant relationship between foreign ownership structure and dividend per share as $p=$ 0.791 . Therefore, this study could not identify any relationship between foreign ownership structure and dividend per share. Firm size is significantly associated with dividend per share at 0.01 level. Also, there is a positive weak relationship between them.

\subsection{VIF test}

Table 4.3: Result of VIF test

\begin{tabular}{lcc}
\hline \multicolumn{1}{c}{ Variable } & \multicolumn{2}{c}{ Collinearity Statistics } \\
& Tolerance & VIF \\
\hline Institutional ownership & .333 & 2.999 \\
Managerial ownership & .337 & 2.968 \\
Foreign ownership & .879 & 1.138 \\
Firm Size & .830 & 1.205 \\
Firm Leverage & .942 & 1.061 \\
\hline
\end{tabular}

VIF test is important to avoid multicollinearity (correlation between predictors) exists in a regression analysis. Table 4.3 shows an absence of multicollinearity as VIF ranges are from 1.061 to 2.999 which are lower than limit of 5. This result indicates that there is no collinearity among the explanatory variables. 
4.4 Multiple regression analysis

Table 4.4: Result of Multiple Regression Analysis

\begin{tabular}{|c|c|c|c|c|c|}
\hline & B & Std. Error & Beta & $\mathrm{T}$ & Sig. \\
\hline (Constant) & -12.342 & 7.686 & & -1.606 & .111 \\
\hline IOS & -6.810 & 3.448 & -.284 & -1.975 & .049 \\
\hline MOS & .296 & 3.320 & .013 & 0.089 & .929 \\
\hline FOS & -1.084 & 1.308 & -.074 & -.829 & .409 \\
\hline FSZ & 1.843 & .807 & .208 & 2.283 & .024 \\
\hline FLV & -2.755 & 4.482 & -.053 & -.615 & .540 \\
\hline$R 2=.124$ & $R 2=.08$ & \multicolumn{2}{|c|}{$F=4.134$} & Statist & 0.002 \\
\hline
\end{tabular}

a. Dependent Variable: DPS

$D P S=-12.342-6.81010 S+0.296$ MOS $-1.084 F O S+1.843 F S Z-2.755 F L V+\varepsilon$

Result of multiple regression analysis shows that $12.4 \%$ changes in dividend per share is determined by selected ownership structure in this study, namely institutional ownership structure, managerial ownership structure and foreign ownership structure, as $\mathrm{R}^{2}$ is 0.124 (significant at 0.01 ). Remaining $87.6 \%$ of variability in dividend per share is explained by other factors which are not indicated in this model.

The coefficient of institutional ownership structure is -6.810 , which indicates that institutional ownership structure has negative impact on dividend per share. They are significant at 0.05 level $(p=0.049)$. There is no significant impact of managerial ownership structure and foreign ownership structure on dividend per share, as $p=0.929$ and $p=0.409$ respectively. Therefore, this study could not identify any impact of managerial ownership structure and foreign ownership structure on dividend per share.

According to the multiple regression analysis, hypotheses of this study has been tested. $H_{1 a}$ indicated that there is a significant relationship between institutional ownership structure and dividend per share. It is supported to the finding of this study as $p$ value $(0.049)$ of institutional ownership structure is significant at 0.05 level. It is consistent with findings of Farinha (2003), Shariff, Salehi, and Bahadori 
(2010), Abdullah, Ahmad, and Roslan, (2012), Abdelsalam, El-Masry, and Elsegini (2008), Gharaibeh, Zurigat, and Harahsheh, (2013), Short, Zhang, and Keasey, (2002) and Ullah, Fida, and Khan (2012). P value (0.929) of managerial ownership structure does not have significant relationship with dividend per share. Thud, $\mathrm{H}_{1 \mathrm{~b}}$, which stated that there is a significant relationship between managerial ownership structure and dividend per share, is not supported to the finding of this study. It is consistent with findings of previous researches conducted by Strouraitis and $\mathrm{Wu}$ (2004) and Kumar (2003). $\mathrm{H}_{1 \mathrm{c}}$ stated that there is a significant relationship between foreign ownership structure and dividend per share. It is also not supported to the finding of this study as $p$ value $(0.409)$ of foreign ownership structure doesn't have significant relationship with dividend per share at 0.05 level. Warred et al. (2012) and Abdullah et al. (2012) have revealed similar finding in their studies. Firm size is positively and significantly correlated with dividend per share $(r=1.843, p=0.024)$.

\section{Conclusion}

This study has been carried out to examine the relationship between ownership structure and dividend per share as it is important to understand various factors influencing on dividend per share of manufacturing companies in Sri Lanka. Descriptive statistics indicates that highest mean value falls with institutional ownership structure among selected four ownership structures. Thus, this study indicates that there may be low level awareness among other parties to have an ownership in manufacturing companies in Sri Lanka. According to the correlation analysis, there is a significant negative relationship of institutional ownership structure and managerial ownership structure with dividend per share. Foreign ownership structure has insignificant relationship with dividend per share. Based on the regression analysis, this study has found that institutional ownership structures has negative significant impact on dividend per share while managerial and foreign ownership structures do not have significant impact on dividend per share. 
There have been few studies that examined the relationship between the ownership structure and dividend per share but there are no recent studies on this concept in the Sri Lankan emerging market. Therefore, this study extents the literature by examining how different types of ownership structures impact on dividend per share. Findings of this study are useful to regulators for future direction in the CSE and the results will be helpful to investors for predicting firms' dividend payouts and valuation of their stocks regarding the changes of different ownership structures. Future survey may be conducted using data collected from all companies listed in the Colombo stock exchange in Sri Lanka. Also, there are various ownership structures rather than selected four ownership structures in this study to carry out the research in the future.

\section{Acknowledgement:}

The present work was benefited from the input of Miss S. Tharmika, undergraduate student at University of Jaffna, who provided valuable assistance to summarize data.

\section{References}

Abdelsalam, O., El-Masry, A. \& Elsegini, S. (2008). Board composition, ownership structure and dividend policies in an emerging market: Further evidence from CASE 50. Managerial Finance. 34 (12): 953-964.

Abdullah, N. M. H., Ahmad, Z., \& Roslan, S. (2012). The influence of ownership structure on the firms' dividend policy based lintner model. International review of business research papers. 8(6):71-88.

Adeiza, M. K., Kabiru, I. D., \& Muhibudeen, L. (2015). Corporate shareholding structure and dividend payout ratio of listed chemical and paints companies in Nigeria. Applied finance and accounting. 1(2): 48-53.

Afza, T., \& Mirza, H.H. (2010). Ownership structure and cash flows as determinants of corporate dividend policy in Pakistan. International business research. 3(3):210-221. 
Afzal, M. \& Sehrish, S. (2010). Ownership structure, board composition and dividend policy in Pakistan. COMSATS institute of information technology, Islamabad, Pakistan.

Ayunku, P.E. \& Etale, L.M. (2016). Dividend payout policy and firm performance: Evidence from Nigeria. Social science learning education journal, 1(1): 6-9.

Besley, S. \& Brigham, E.F. (2008). Essentials of managerial finance. The dryden press, Orlando, Florida.

Bhat, S. (2008). Financial Management: Principles and practice. New Delhi: Excel books. New Delhi, India.

Dionne, G. \& Ouederni, K. (2011). Corporate risk management and dividend signaling theory. Finance Research Letters, 8(4): 188-195.

Ehsan, S., Tabassum, N., Akram, Z., \& Nasir, R. (2013). Role of insider and individual ownership structure in dividend payout policy: Evidence from Pakistan. Middle-East journal of scientific research. 17(9): 1316-1326.

Farinha, J. (2002). Dividend policy, corporate governance and the managerial entrenchment hypothesis: An empirical analysis. Journal of business finance \& accounting. 30(9-10): 1173-1209.

Gharaibeh, M., Zurigat, Z., \& Harahsheh, K. (2013). The Effect of ownership structure on dividends policy in Jordanian companies. Interdisciplinary journal of contemporary research in business. 4(9):769-796.

Jensen, M.C., \& Meckling, W.H. (1976). Theory of the firm: managerial behavior, agency costs and ownership structure. The journal of financial economics, 3(4): 305-360

Kumar, J. (2003). Ownership structure and dividend payout policy in India. Journal of emerging market finance. 5(1):15-58. 
Lina, W., Suzan, A, Ola, K. \& Imad, A. (2012). The effect of ownership structure on dividend payout policy: evidence from Jordanian context. International journal of economics and finance, 4 (2):187-195.

Mapitiya, G.S., Ajward, A.R, \& Samanthi, S. (2015). Ownership concentration and degree of compliance with corporate governance best practices of public listed companies in Sri Lanka. National School of Business Management (NSBM) journal of management, 1(1):103-118.

Miller, M.H., \& Modigliani, F. (1961). Dividend policy, growth, and the valuation of shares. The journal of business. 34(4): 411-433.

Minimol, M.C. \& Makesh, K.G. (2013). Impact of foreign institutional investors on corporate dividend policy in India. India journal of research. 3(4):180-182.

Mirzael, H. (2012). A survey of the relationship between ownership structure and dividend policy in Tehran stock exchange. Proceedings of international conference on management, applied and social sciences, Dubai.

Nuraddeen, U.M. \& Hasnah, K. (2015). Ownership structure and dividend policy of conglomerates firms in Nigeria. Academic Journal of Interdisciplinary Studies. 4(2): 279-285.

Pamela, P. D. \& Frank, J. F. (2010). The basics of finance: an introduction to financial markets, business finance and portfolio management, John Wiley \& Sons Inc. U.S.A.

ShahSyed. Z., Ullah, W. \& Hasnain, B. (2010). Impact of ownership structure on dividend policy of firms: evidence from Pakistan. Proceedings of international conference on e-business, management and economics. Hong Kong.

Sharif, S.J.S., Salehi, M. \& Bahadori, H. (2010). Ownership structure of Iranian evidence and payout ratio. Asian social science. 6(7): 36 - 42 
Short, H., Zhang, H., \& Keasey, K. (2002). The link between dividend policy and institutional ownership. Journal of corporate finance. 8(2):105-122.

Tahir, S.H., Aslam, M.A., \& Akhtar, M.A. (2014). The impact of board composition and ownership structure on dividend policy in Pakistan. Research journal of economics and business studies. 3(6):18-24.

Ullah, H., Fida, A., \& Khan, S. (2012). The impact of ownership structure on dividend policy evidence from emerging markets KSE-100 Index Pakistan. International journal of business and social science. 3(9): 298-307.

Warrad, L., Abed, S., Khriasat, O., \& Al-Sheikh, I. (2012).The effect of ownership structure on dividend payout policy: evidence from Jordanian context, International journal of economics and finance. 4(2):187-195. 